AGRITECH, Vol. 37, No. 3, Agustus 2017, Hal. 237-245

DOI: http://doi.org/10.22146/agritech.16656

ISSN 0216-0455 (Print), ISSN 2527-3825 (Online)

Tersedia online di https://jurnal.ugm.ac.id/agritech/

\title{
Identifikasi Gen Transgenik pada Produk Susu Bubuk Kedelai dan Susu Formula Soya dengan Metode PCR (Polymerase Chain Reaction)
}

\author{
Identification of Transgenic Genes in Soy Milk Powders and Soy Formulas with Polymerase Chain Reaction (PCR) \\ Technique
}

\author{
Agustin Krisna Wardani ${ }^{\star}$, Annisa Arlisyah, Ana Fauziah, Titik Nur Fa'ida \\ Jurusan Teknologi Hasil Pertanian, Fakultas Teknologi Pertanian, Universitas Brawijaya \\ Jl. Veteran, Malang 65145, Indonesia \\ Email: agustinwardani@ub.ac.id
}

Submisi: 20 Januari 2016; Penerimaan: 14 Desember 2016

\begin{abstract}
ABSTRAK
Kebutuhan kedelai yang mencapai 2,54 juta ton/tahun memaksa Indonesia mengimpor sebanyak 1,5 juta ton. Sebagian besar kedelai impor berupa kedelai transgenik. Dengan munculnya kedelai transgenik di Indonesia, perlu adanya pelabelan Produk Rekayasa Genetika (PRG) untuk memenuhi hak-hak konsumen. Teknik yang dilakukan untuk mendeteksi PRG salah satunya menggunakan metode PCR. Penelitian ini bertujuan untuk mengetahui ada tidaknya gen transgenik pada produk susu bubuk kedelai dan formula soya, sehingga produk dapat digolongkan sebagai PRG atau tidak. Penelitian juga bertujuan untuk mengetahui suhu annealing optimum primer CaMV 35S promotor, gen EPSPS$\mathrm{CP} 4$, dan NOS terminator yang diaplikasikan dalam penelitian ini. Hasil penelitian didapatkan suhu annealing optimum primer CaMV 35S promotor adalah $60^{\circ} \mathrm{C}$. Sedangkan untuk primer gen EPSPS-CP4 suhu annealing optimumnya 59 ${ }^{\circ} \mathrm{C}$. Untuk primer NOS terminator suhu annealing optimum tidak ditemukan. Dari amplifikasi DNA sampel, 6 sampel susu bubuk kedelai dan 5 sampel formula soya terdapat sisipan gen EPSPS-CP4 dan gen Promotor CaMV 35S. Dengan demikian 11 sampel tersebut dapat dikatakan sebagai PRG.
\end{abstract}

Kata kunci: Produk rekayasa genetika; PCR; formula soya; susu kedelai bubuk; kedelai transgenik

\begin{abstract}
The need of soybean that reached up to 2,54 million tons per year has made Indonesia imports this commodity as much as 1,5 million tons from countries that adopt Genetically Modified (GM) soybean. By the presence of GM soybeans in Indonesia, Genetically Modified Product (GMP) labelling has need to be done. Detection of GMP can be done by using PCR. The first aim of this study was to determine the presence of trangenic genetic material in soy milk powder and soy formula products to classify as GMP. Another goal was to determine the optimum annealing temperature of the primers used. Based on this study, the optimum annealing temperature of the CaMV 35S primer and the EPSPS-CP4 primer were $60^{\circ} \mathrm{C}$ and $59^{\circ} \mathrm{C}$, respectively. The NOS terminator primer's optimum annealing temperature was not found. 6 soy milk powder samples and 5 soy formula samples are might be determined to be using transgenic soybeans due to the presence of EPSPS-CP4 genes and CaMV 35S promotor genes. Therefore, those 11 samples were classified as GMP.
\end{abstract}

Keywords: GMO; PCR; soy formula; soy powder milk; transgenic soybean 


\section{PENDAHULUAN}

Susu kedelai saat ini mulai diminati masyarakat ditinjau dari proteinnya yang tidak jauh berbeda dengan susu sapi baik untuk dewasa ataupun untuk anak-anak. Susu kedelai yang tidak memiliki kasein dan laktosa dikonsumsi terutama oleh penderita lactose intolerance dan autisme sebagai pengganti susu sapi (Kilamanca, 2008). Kebutuhan domestik kedelai $70 \%$ masih impor dikarenakan rendahnya produksi dalam negeri (Satria, 2015). Kedelai impor di Indonesia hampir setengahnya berasal dari Amerika Serikat (AS), dimana menurut Olson (2015) kedelai di AS 94\% merupakan kedelai transgenik. Dengan munculnya kedelai transgenik di Indonesia, keterbukaan dalam dunia konsumsi menuntut adanya pelabelan PRG. Pentingnya kajian ini berdasarkan pemberian perlindungan hak-hak universal konsumen khususnya terhadap PRG yang beresiko terhadap kesehatan dan lingkungan. Selain itu juga bertujuan membantu terciptanya sistem pelabelan PRG di Indonesia.

Deteksi adanya gen transgenik pada produk berbasis kedelai bisa dilakukan menggunakan metode Dot-Blot (Putra dkk., 2014), ELISA(Folloni dkk., 2011), dan SERS (Chen dkk., 2012). Namun, ketiga metode tersebut memiliki kelemahan dimana metode ELISA memiliki sensitivitas rendah, aplikasi SERS relatif mahal biayanya dan Dot-blot memiliki efisiensi rendah. Metode lain yang dapat dilakukan adalah PCR, dimana merupakan teknik amplifikasi DNA secara in vitro pada daerah spesifik yang dibatasi oleh dua buah primer oligonukleotida dengan bantuan enzim polymerase (Ilhak dan Arslan, 2007). Metode PCR unggul baik dari spesifisitasnya, efisiensinya dan keakuratannya (Yusuf, 2010). Faktor penting yang mempengaruhi keberhasilan amplifikasi DNA ada pada tahap annealing, jika suhu terlalu tinggi dapat mendegradasi primer sehingga dapat terjadi mispriming, sedangkan jika suhu terlalu rendah maka DNA yang terbentuk memiliki spesifisitas rendah (Handoyo dan Ari, 2000). Optimasi suhu annealing pada proses PCR penting untuk dilakukan agar amplifikasi DNA dapat berjalan secara optimal.

Kedelai transgenik yang diproduksi oleh Monsanto secara umum tersisipi oleh gen asing EPSPS-CP4 yang bertujuan untuk melindungi tanaman dari herbisida Roundup Ready. Selain itu, sisipan gen CaMV (Cauliflower Mosaic Virus) 35S Promotor, dan Nos Terminator (non-translated region dari napoline syntase gene) juga diintroduksikan pada tanaman (Windels, 2001).

Penelitian ini bertujuan untuk mengetahui ada tidaknya gen transgenik pada produk susu bubuk kedelai dan formula soya, sehingga produk dapat digolongkan sebagai PRG atau tidak. Penelitian juga bertujuan untuk mengetahui suhu annealing optimum primer CaMV $35 \mathrm{~S}$ promotor, gen EPSPS-CP4, dan NOS terminator yang diaplikasikan dalam penelitian ini.

\section{METODE PENELITIAN}

\section{Alat dan Bahan}

Sampel yang digunakan dalam penelitian ini meliputi 12 susu kedelai bubuk bermerk dan 8 sampel formula soya. Pada penelitian ini primer yang digunakan adalah gen promotor dari CaMV, primer target sekuen EPSPS-CP4, dan primer NOS Terminator (Sorina dkk., 2006; Meric dkk., 2014; Tung dkk., 2008). Ketiga primer tersebut dipesan dari Macrogen. Sekuens primer dapat dilihat pada Tabel 3. Kontrol positif berupa kedelai merk Berlian yang diimpor dari Amerika Serikat, sedangkan kontrol negatif adalah kedelai lokal Autralia.

Sedangkan reagen bahan isolasi digunakan lysis buffer (CTAB, BME, EDTA, Tris-Cl, $\mathrm{NaCl}$ ), Proteinase-K, PCI (phenol:chloroform:isoamylalcohol), $\mathrm{CI}$ (chloroform:isoamyl alcohol), etanol absolut, etanol 70\%, dan TE buffer (EDTA Tris-Cl). Untuk elektroforesis digunakan agarosa, EtBr (Ethidium Bromide), loading dye, marker (100-1000 bp ladder marker) (Thermo Scientific), nuclease-free water, TAE buffer (EDTA, tris-base, AAG). Untuk bahan PCR digunakan Go Tag Green Mix (Promega), DNA template, dan $\mathrm{ddH}_{2} \mathrm{O}$.

Alat yang digunakan dalam penelitian ini antara lain mesin Polymerase Chain Reaction (PCR) (Amplified Biosystem), seperangkat alat DNA elektroforesis (Bio-Rad), Gel Doc (Bio-Rad), nanodrop spektrofotometer (NanoDrop ND-1000-UV-Vis Spectrophotometer), shaker waterbath (Memmert), sentrifuse dingin (Hettich Zentrifugen), micropipette (Eppendorf dan Finnpipette), pH meter (Hanna), glassware, timbangan analitik (Ohaus), freezer (Sharp), dan autoclave (Tomy ES315).

\section{Pengambilan Sampel}

Teknik pengambilan sampel dilakukan dengan metode acak sederhana. Sampel susu bubuk kedelai bermerk diperoleh dari supermarket Lai-Lai (5 sampel), Pasar Minggu (1 sampel), dan apotik Kimia Farma (6 sampel) di kota Malang. Untuk sampel formula soya didapatkan dari supermarket LaiLai (2 sampel), supermarket Hypermart Matos (2 sampel), dan toko Prima Grosir (4 sampel).

\section{Ekstraksi dan Purifikasi DNA}

Metode ekstraksi dan purifikasi DNA menggunakan metode CTAB Cetyl Trimethyl Ammonium Bromide) (Jankiewicz dkk., 1999) dengan modifikasi dari Rahmawati (2011) dengan penambahan $\beta$-mercaptoetanol 0,2\%. Sampel dilarutkan dengan akuades dalam tabung reaksi kemudian dihomogenisasi dengan vortex. Setelah itu masing-masing sampel diambil airnya dan dimasukkan dalam microtube lalu ditambahkan CTAB buffer lysis dan proteinase-K, lalu diinkubasi selama 30 menit dengan waterbath suhu $65{ }^{\circ} \mathrm{C}$. 
Sampel kemudian disentrifugasi, tiap sentrifugasi dilakukan dengan $10.000 \mathrm{rpm}$ dengan suhu $4{ }^{\circ} \mathrm{C}$ selama 10 menit. Setelah itu, supernatan dipindahkan ke microtube baru dan ditambahkan larutan PCI dengan volume 2 kali dari larutan sebelumnya, lalu dihomogenisasi. Selanjutnya sampel disentrifugasi, dan supernatan dipindahkan ke microtube baru dan ditambahkan larutan CI dengan 2 kali lipat dari volume sebelumnya, setelah itu dihomogenisasi. Sampel kemudian disentrifugasi, supernatan dipindahkan ke microtube baru dan ditambahkan etanol absolut sebanyak 2 kali lipat dari volume sebelumnya lalu diinkubasi dalam freezer $\left(-20{ }^{\circ} \mathrm{C}\right)$ selama 30 menit. Sampel disentrifugasi kembali dengan aturan yang sama, supernatan dibuang dan pelet yang tertinggal ditambahkan $200 \mu \mathrm{L}$ etanol $70 \%$ lalu dibolakbalik. Kemudian sampel disentrifugasi lagi dan supernatan dibuang dan sisanya diuapkan pada oven suhu $55^{\circ} \mathrm{C}$ selama kurang lebih 30 menit. Pelet yang tertinggal dielusi dengan buffer TE $50 \mu \mathrm{L}$ masing-masing sampel dan hasil isolat DNA disimpan pada suhu $-20{ }^{\circ} \mathrm{C}$. Isolat DNA kemudian diukur konsentrasi dan kemurniannya menggunakan alat NanoDrop spectrophotometer.

\section{Optimasi Suhu Annealing PCR dan Amplifikasi DNA Sampel}

Untuk primer yang digunakan dapat dilihat pada Tabel 1. Penentuan range suhu annealing diperoleh dari pengurangan 2 derajat suhu dari nilai Tm, dimana tiap primer diperoleh 2 nilai Tm, yakni dari rekomendasi Macrogen dan hasil hitungan rumus. Sehingga optimasi suhu annealing PCR dilakukan 12 kali sesuai dengan jumlah titik suhu annealing, yaitu untuk primer P35S meliputi suhu $45,47,58$, dan $60{ }^{\circ} \mathrm{C}$, dan untuk primer RRS0t meliputi suhu 44, 46, 57, dan 59 ${ }^{\circ} \mathrm{C}$, sedangkan untukprimer HAnos meliputi 50, 52, 63, dan $65{ }^{\circ} \mathrm{C}$. Komposisi PCR dapat dilihat pada Tabel 2. Bahan-

Tabel 1. Primer yang digunakan untuk mendeteksi gen transgenik

\begin{tabular}{|c|c|c|c|}
\hline & Jenis primer & Urutan DNA & $\begin{array}{c}\text { Panjang } \\
\text { DNA }\end{array}$ \\
\hline \multicolumn{4}{|c|}{ CaMV 35S promoter } \\
\hline \multicolumn{2}{|c|}{ * } & 5'-CCACGTCTTCAAAGCAAGTGG-3' & $123 b p$ \\
\hline \multicolumn{2}{|c|}{ P35S-cf3 (forward) } & 5'-TCСТCTCСAAATGAAATGAACTTCC-3' & \\
\hline \multicolumn{4}{|c|}{ P35S-cr4 (reverse) } \\
\hline \multicolumn{2}{|c|}{ NOS terminator $* *$} & 5'-GCATGACGTTATTTATGAGATGGG-3' & $118 \mathrm{bp}$ \\
\hline \multicolumn{2}{|c|}{$\begin{array}{l}\text { HA nos1 18-F } \\
\text { (forward) }\end{array}$} & 5'-GACACCGCGCGCGATAATTTATCC-3' & \\
\hline \multicolumn{2}{|c|}{ HA nos $118-\mathrm{R}$} & 5'-CCTTTAGGATTTCAGCATCAGTG-3' & $121 \mathrm{bp}$ \\
\hline \multicolumn{2}{|c|}{ (reverse) } & 5'-GACTTGTCGCCGGGAATG-3' & \\
\hline \multicolumn{4}{|c|}{ EPSPS-CP4 $* * *$} \\
\hline \multicolumn{4}{|c|}{ RRS0t-5 (forward) } \\
\hline \multicolumn{4}{|c|}{ RRS01-3 (reverse) } \\
\hline \multicolumn{4}{|c|}{ Sorina dkk. (2006) } \\
\hline \multicolumn{4}{|c|}{ ** $\quad$ Meric dkk. (2014) } \\
\hline \multicolumn{4}{|c|}{ *** Tung dkk. (2008) } \\
\hline
\end{tabular}

Tabel 2. Komposisi reaksi PCR

\begin{tabular}{|c|c|}
\hline Komponen & Volume \\
\hline $\begin{array}{l}\text { Master mix PCR (taq polymerase, buffer Taq, } \\
\mathrm{MgSo}_{4} \text {, dan dNTP) }\end{array}$ & $12,5 \mu \mathrm{L}$ \\
\hline Primer F $(10 \rho \mathrm{mol} / \mu \mathrm{L})$ & $1,0 \mu \mathrm{L}$ \\
\hline Primer R $(10 \rho \mathrm{mol} / \mu \mathrm{L})$ & $1,0 \mu \mathrm{L}$ \\
\hline DNA template (asumsi konsentrasi $\pm 20 \mathrm{ng} / \mu \mathrm{L}$ ) & $1,0 \mu \mathrm{L}$ \\
\hline $\mathrm{ddH}_{2} \mathrm{O}$ & $9,5 \mu \mathrm{L}$ \\
\hline Total & $25,0 \mu \mathrm{L}$ \\
\hline
\end{tabular}

Tabel 3. Program PCR

\begin{tabular}{|c|c|c|}
\hline Tahapan PCR & Suhu $\left({ }^{\circ} \mathrm{C}\right)$ & $\begin{array}{c}\text { Waktu } \\
\text { (menit:detik) }\end{array}$ \\
\hline \multicolumn{3}{|c|}{ Primer P35S (35 siklus) * } \\
\hline Initial denaturation & 95 & 05:00 \\
\hline Denaturation & 95 & $00: 30$ \\
\hline Annealing & $45-60$ & $00: 30$ \\
\hline Extention & 72 & $00: 30$ \\
\hline Final extention & 72 & 05:00 \\
\hline Waiting & 4 & \\
\hline \multicolumn{3}{|c|}{ Primer RRS0t (35 siklus)*** } \\
\hline Initial denaturation & 95 & 05:00 \\
\hline Denaturation & 95 & 00:40 \\
\hline Annealing & $44-59$ & $00: 40$ \\
\hline Extension & 72 & $00: 40$ \\
\hline Final extention & 72 & 05:00 \\
\hline Waiting & 4 & \\
\hline \multicolumn{3}{|c|}{ Primer HAnos (50 siklus) $* * *$} \\
\hline Initial denaturation & 95 & 10:00 \\
\hline Denaturation & 95 & $00: 25$ \\
\hline Annealing & $50-65$ & $00: 30$ \\
\hline & 72 & $00: 45$ \\
\hline Extension & 72 & 07:00 \\
\hline Final extension & 4 & \\
\hline \multicolumn{3}{|l|}{ Waiting } \\
\hline * Sorina dkk. (2006) & & \\
\hline ** $\quad$ Meric dkk. (2014) & & \\
\hline *** Tung dkk. (2008) & & \\
\hline
\end{tabular}

bahan tersebut dicampur ke dalam thin wall lalu dilakukan amplifikasi DNA dengan mesin PCR. Program PCR untuk optimasi dapat dilihat pada Tabel 3. Sampel DNA yang digunakan pada proses optimasi PCR penelitian ini adalah kontrol positif.

\section{Visualisasi Hasil Amplifikasi DNA}

Konfirmasi hasil amplifikasi divisualisasi menggunakan elektroforesis gel agarosa 3\%. Pembuatan gel dilakukan dengan menimbang agarosa sebanyak 1,2 $\mathrm{g}$ dan dilarutkan 
dalam $40 \mathrm{~mL}$ TAE buffer $1 \times$. Selanjutnya dipanaskan diatas kompor listrik hingga larutan bening. Setelah itu didiamkan hingga larutan hangat lalu ditambah EtBr sebanyak $1 \mu \mathrm{L}$ dan dihomogenisasi, lalu dituang ke dalam cetakan yang telah dipasang sisir dan ditunggu hingga gel memadat. Setelah itu gel diberi larutan TAE buffer $1 \times$ hingga terendam. Kemudian dilakukan proses loading sampel ke dalam sumur-sumur yang terdapat pada gel. Setelah itu dilakukan elektroforesis dengan tegangan 60 Volt selama lebih kurang 1,2 jam. Setelah selesai, gel divisualisasi dengan menggunakan alat Gel-Doc XR 1000.

\section{HASIL DAN PEMBAHASAN}

\section{Isolasi DNA Sampel dan Pengukuran Kuantitaif DNA}

Keberadaan DNA pada penelitian ini selanjutnya diketahui secara kuantitatif menggunakan alat Nanodrop Spectrophotometer. Hasil pengukuran kuantitatif Isolasi DNA dapat dilihat pada Tabel 4.

Hasil nilai kemurnian isolasi DNA sampel berkisar antara 0,89-2,16. Kemurnian DNA tergolong baik menurut Termos Fisher Scientific (2008) jika memiliki nilai berkisar antara 1,8-2,0. DNA yang memiliki nilai kemurnian dibawah 1,8 menunjukkan adanya kontaminasi protein, sedangkan yang memiliki nilai kemurnian diatas 2,0 menunjukkan adanya kontaminasi RNA. Sampel B, C, E, F, G, H, I, J, M, P, Q, dan $\mathrm{S}$ menunjukkan adanya kontaminasi oleh protein pada isolat DNA sampel. Hal ini diduga karena kurang maksimalnya pada saat presipitasi DNA sampel dengan menggunakan PCI. Phenol berfungsi untuk membersihkan sisa-sisa protein yang masih terdapat pada isolat DNA sementara pemberian senyawa kimia kloroform dapat menyebabkan lisisnya membran sel serta terdenaturasinya protein-protein seperti endonuklease. Isoamil alkohol digunakan untuk mengurangi buih ketika ekstraksi berlangsung (Sambrook, dan Russel, 2001). Selain itu juga dapat disebabkan karena kurangnya waktu inkubasi menggunakan buffer lysis dan proteinase-K. Sampel K, L, N, dan $\mathrm{O}$ menunjukkan adanya kontaminasi RNA. Hal ini dapat disebabkan karena tidak adanya penambahan enzim RNAse yang berfungsi untuk mendegradasi RNA. EnzimRNAse dalam proses isolasi DNA yang berfungsi untuk mengurangi kontaminasi RNA (Sari dan Wardani, 2015).

Konsentrasi DNA hasil ekstraksi bervariasi antara 95,96-5138,85 ng/ $\mu \mathrm{L}$. Hal ini diduga disebabkan sampel yang diekstraksi berasal dari proses pengolahan yang berbeda. Selain itu, adanya bahan campuran dalam suatu produk mempengaruhi konsentrasi DNA yang diperoleh. Bahan dan bumbu-bumbu yang ditambahkan dalam produk olahan menyebabkan DNA yang diekstraksi masih tercampur dengan senyawa kontaminan seperti oligopeptida, polisakarida, protein dan bahan-bahan organik lainnya (Nazir, 2005).
Tabel 4. Hasil pengukuran konsentasi dan kemurnian DNA sampel

\begin{tabular}{|c|c|c|c|c|}
\hline Sampel & $\begin{array}{c}\text { Konsentrasi } \\
(\mathrm{ng} / \boldsymbol{\mu} \mathbf{L})\end{array}$ & A260 & A 280 & $\begin{array}{c}\text { Kemurnian } \\
(260 / 280)\end{array}$ \\
\hline $\mathrm{A}$ & 3142,11 & 0,063 & 0,032 & 1,97 \\
\hline B & 153,80 & 0,034 & 0,032 & 1,06 \\
\hline $\mathrm{C}$ & 418,20 & 0,008 & 0,007 & 1,14 \\
\hline $\mathrm{D}$ & 1500,09 & 0,030 & 0,017 & 1,76 \\
\hline E & 572,54 & 0,011 & 0,008 & 1,37 \\
\hline $\mathrm{F}$ & 1838,86 & 0,037 & 0,021 & 1,76 \\
\hline G & 1118,50 & 0,022 & 0,017 & 1,29 \\
\hline $\mathrm{H}$ & 1037,36 & 0,021 & 0,013 & 1,62 \\
\hline I & 5138,85 & 0,102 & 0,059 & 1,72 \\
\hline $\mathrm{J}$ & 2448,09 & 0,049 & 0,028 & 1,75 \\
\hline K & 2151,71 & 0,043 & 0,021 & 2,04 \\
\hline $\mathrm{L}$ & 2615,03 & 0,052 & 0,025 & 2,08 \\
\hline M & 95,96 & 0,019 & 0,017 & 1,11 \\
\hline $\mathrm{N}$ & 456,50 & 0,091 & 0,042 & 2,16 \\
\hline $\mathrm{O}$ & 743,28 & 0,148 & 0,072 & 2,05 \\
\hline $\mathrm{P}$ & 1868,25 & 0,373 & 0,216 & 1,72 \\
\hline Q & 234,57 & 0,047 & 0,053 & 0,89 \\
\hline $\mathrm{R}$ & 1309,61 & 0,261 & 0,145 & 1,86 \\
\hline S & 134,28 & 0,027 & 0,020 & 1,34 \\
\hline $\mathrm{T}$ & 3142,11 & 0,333 & 0,169 & 1,97 \\
\hline $\mathrm{K}+$ & 153,80 & 0,010 & 0,006 & 1,67 \\
\hline $\mathrm{K}-$ & 418,20 & 0,052 & 0,034 & 1,53 \\
\hline
\end{tabular}

Keterangan :

$\mathrm{A}-\mathrm{L}=$ sampel susu bubuk kedelai

$\mathrm{M}-\mathrm{T}=$ sampel formula soya

$\mathrm{K}+\quad=$ kontrol positif

$\mathrm{K}-\quad=$ kontrol negatif

\section{Optimasi Suhu Annealing PCR}

Untuk mendapatkan hasil PCR yang optimal perlu dilakukan proses optimasi PCR. Ketepatan penggunaan suhu annealing berpengaruh terhadap proses penempelan primer terhadap DNA template(Grunewald, 2003). Sekuens primer dapat dilihat pada Tabel 3. Kondisi PCR yang diprogram pada optimasi dapat dilihat pada Tabel 2.

\section{Primer promotor CaMV 35S}

Suhu annealing optimum yang dapat digunakan dapat dilihat dari pita DNA yang lebih jelas, dan nyata dibanding suhu annealing lainnya. Hasil optimasi yang terdapat pada Gambar 1 menunjukkan pada tiga sumuran muncul pita dengan ukuran amplikon 123 bp. Namun, pada sumuran 4 terbentuk pita yang sangat jelas dan lebih tebal dibandingkan pada sumuran yang lainnya. Dari hasil tersebut diperoleh 
hasil bahwa pada suhu $60{ }^{\circ} \mathrm{C}$ merupakan suhu yang optimal untuk melakukan annealing pada proses PCR.

\section{Primer gen EPSPS-CP4}

Hasil optimasi pada sumuran 4 yang terlihat pada Gambar 2 menunjukkan terbentuknya pita yang lebih jelas dan lebih tebal dibandingkan pada sumuran yang lainnya. Dari hasil tersebut diperoleh suhu yang optimal untuk melakukan annealing pada proses PCR adalah suhu $59{ }^{\circ} \mathrm{C}$.

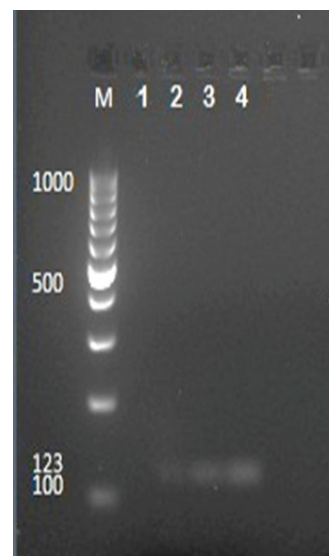

Keterangan:
$\mathrm{M}:$ : Marker
1 : Suhu Annealing $45^{\circ} \mathrm{C}$
2 : Suhu Annealing $47^{\circ} \mathrm{C}$
3 : Suhu Annealing $58^{\circ} \mathrm{C}$
4 : Suhu Annealing $60^{\circ} \mathrm{C}$

Gambar 1. Visualisasi hasil optimasi primer promotor CaMV 35S

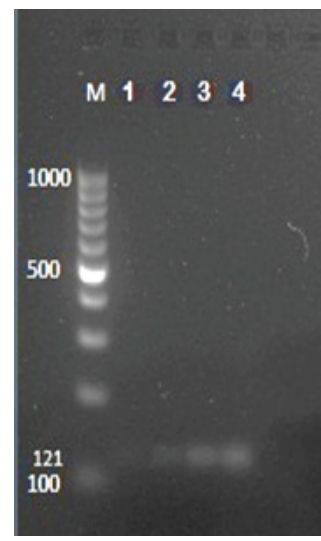

\begin{tabular}{|l|}
\hline Keterangan: \\
$\mathrm{M}:$ Marker \\
1 : Suhu Annealing $44^{\circ} \mathrm{C}$ \\
2 : Suhu Annealing $46^{\circ} \mathrm{C}$ \\
3 : Suhu Annealing $57^{\circ} \mathrm{C}$ \\
4 : Suhu Annealing $59^{\circ} \mathrm{C}$ \\
\hline
\end{tabular}

Gambar 2. Visualisasi hasil optimasi primer gen EPSPS-CP4

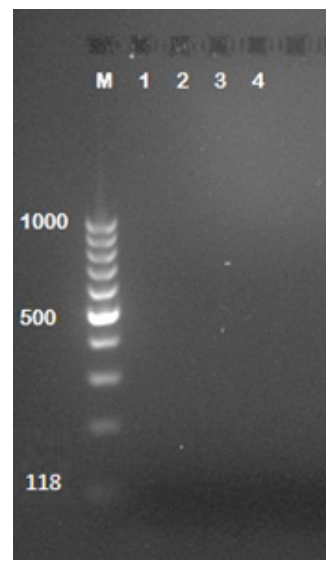

$$
\begin{aligned}
& \text { Keterangan: } \\
& \mathrm{M} \text { : Marker } \\
& 1 \text { : Suhu Annealing } 50^{\circ} \mathrm{C} \\
& 2 \text { : Suhu Annealing } 52^{\circ} \mathrm{C} \\
& 3 \text { : Suhu Annealing } 63^{\circ} \mathrm{C} \\
& 4 \text { : Suhu Annealing } 65^{\circ} \mathrm{C}
\end{aligned}
$$

Gambar 3. Visualisasi hasil optimasi primer NOS terminator

\section{Primer NOS terminator}

Menurut Meric dkk. (2014) jika reaksi amplifikasi berjalan dengan baik dengan suhu annealing diantara salah satu suhu yang diperkirakan, maka akan menghasilkan pita pada ukuran amplikon 118 bp. Namun, pita hasil amplifikasi dari primer NOS terminator tidak muncul, sedangkan pita dari marker muncul. Dari pita marker yang muncul menunjukkan bahwa elektroforesis bekerja dengan baik. Dari hal ini dapat diketahui bahwa hasil amplifikasi oleh pasangan primer NOS terminator tidak berjalan dengan baik menggunakan suhu annealing yang diperkirakan. Hal ini diduga disebabkan dari kontrol positif yang tidak komplementer dengan pasangan primer HAnos-118 untuk mengakhiri proses terminasi transkripsi. Primer NOS terminator juga dapat menggunakan pasangan primer tNOS-2-5' (forward) 5'-GTC TTGCGATGATTATCATATAATTTCTG-3' dan tNOS-23' (reverse) 5'-CGCTATATTTTGTTTTCTATCGCGT-3' dengan hasil amplikon berukuran 151 bp (Meric dkk., 2014).

\section{Amplifikasi DNA Susu Bubuk Kedelai}

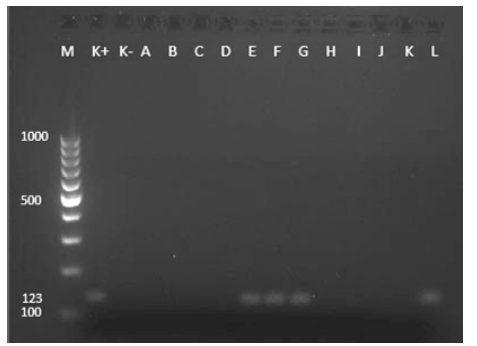

$$
\begin{aligned}
\text { Keterangan: } \\
\mathrm{M}+\quad: \text { Marker } \\
\mathrm{K}+\quad: \text { Kontrol positif } \\
\mathrm{K}-\quad \text { : Kontrol negatif } \\
\mathrm{M}-\mathrm{T}: \text { Sampel susu bubuk } \\
\\
\text { kedelai }
\end{aligned}
$$

Gambar 4. Hasil amplifikasi DNA sampel susu bubuk kedelai dengan primer promotor CaMV $35 \mathrm{~S}$

\section{Primer promotor CaMV 35S}

Menurut Sorina dkk. (2006) pasangan primer P35S-cf3 (forward) dan P35S-cr4 (reverse) memiliki area amplifikasi sebesar 123 bp. Berdasarkan hasil visualisasi pada Gambar 4, primer CaMV 35S dapat mengamplifikasi secara spesifik pada sampel susu bubuk kedelai E, F, G, dan L. Sedangkan pada Sampel A, B, C, D, H, I, J, dan K menunjukkan bahwa tidak terbentuk amplifikasi pita DNA.

Hasil negatif dapat disebabkan DNA yang tidak bersifat komplementer dengan primer Primer bersifat spesifik dan akan menempel pada komplementernya pada DNA template. Pemilihan primer yang tidak sesuai atau tidak komplemen dengan DNA template dapat menyebabkan tidak terjadinya reaksi polimerisasi antara gen target dengan primer (Rahmawati, 2011; Yuwono, 2010). Sampel E, F, $\mathrm{G}$, dan $\mathrm{L}$ teramplifikasi dengan baik. Hal ini ditunjukkan dengan adanya pita DNA yang terlihat jelas, nyata meskipun samar. Hasil amplifikasi dengan primer Promotor CaMV $35 \mathrm{~S}$ terhadap sampel memiliki panjang pita 123 bp. Hal 


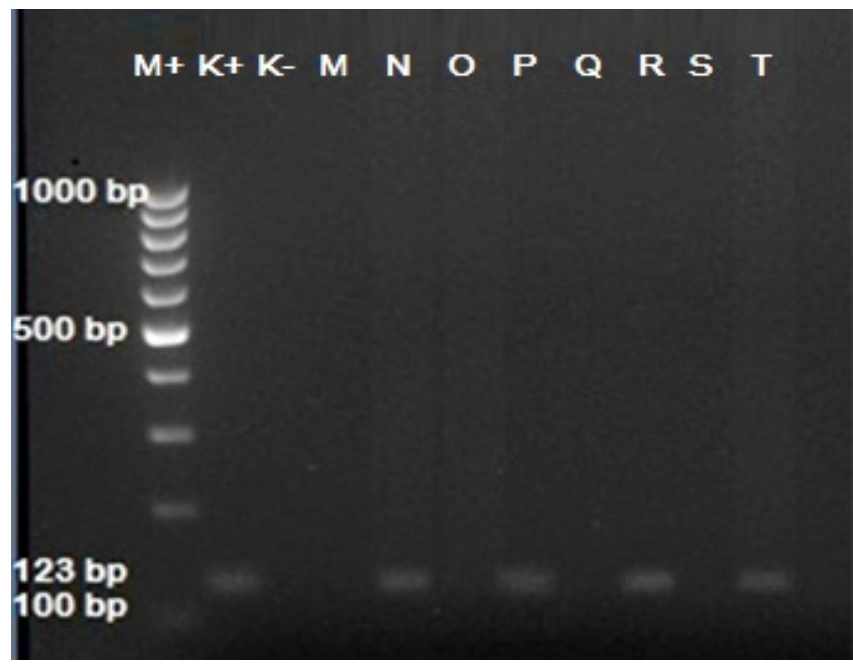

Keterangan:

$\mathrm{M}+\quad$ : Marker

$\mathrm{K}+\quad$ : Kontrol positif

K- : Kontrol negatif

M-T : Sampel susu bubuk

Gambar 5. Hasil amplifikasi DNA sampel formula soya dengan primer promotor CaMV $35 \mathrm{~S}$

ini menunjukkan bahwa di dalam isolat DNA sampel mengandung nukleotida-nukleotida yang berkomplementer dengan sekuen primer bekerja secara spesifik gen CaMV 35S terhadap DNA template (Rahmawati, 2011). Pasangan yang saling berkomplementer tersebut kemudian mengalami pemanjangan oleh enzim polimerase saat tahap elongasi sehingga saat visualisasi dengan elektroforesis muncul pita DNA dengan ukuran 123 bp. Pada gambar, pita yang terbentuk terlihat samar meskipun nyata dan cukup tebal, hal ini dapat disebabkan oleh konsentrasi yang rendah (ratarata $\pm 202 \mathrm{ng} / \mu \mathrm{L}$ ). Konsentrasi DNA berpengaruh pada hasil viualisasi amplifikasi DNA.

Pada Gambar 5, sampel formula soya N, P, R, dan T memperlihatkan terbentuknya pita DNA pada ukuran 123 bp, yang menandakan bahwa primer yang digunakan spesifik terhadap DNA template. Akan tetapi pita DNA yang terbentuk tidak terlalu jelas atau samar, hal tersebut dapat disebabkan karena nilai kemurnian DNA template yang digunakan pada proses PCR masih cukup rendah sehingga mempengaruhi proses polimerisasi atau pemanjangan untai DNA akibatnya jumlah untai DNA yang dihasilkan rendah. Sampel M, O, Q, dan $\mathrm{S}$ tidak terbentuk adanya pita DNA yang menandakan bahwa tidak terjadi amplifikasi pada DNA template yang dapat disebabkan tidak menempelnya primer dengan DNA template. Hal ini dapat disebabkan karena kualitas DNA yang kurang baik yang mengandung kontaminan dan metabolit lain seperti fenol protein. Amplifikasi DNA yang berasal dari pangan olahan dipengaruhi oleh adanya jumlah DNA yang

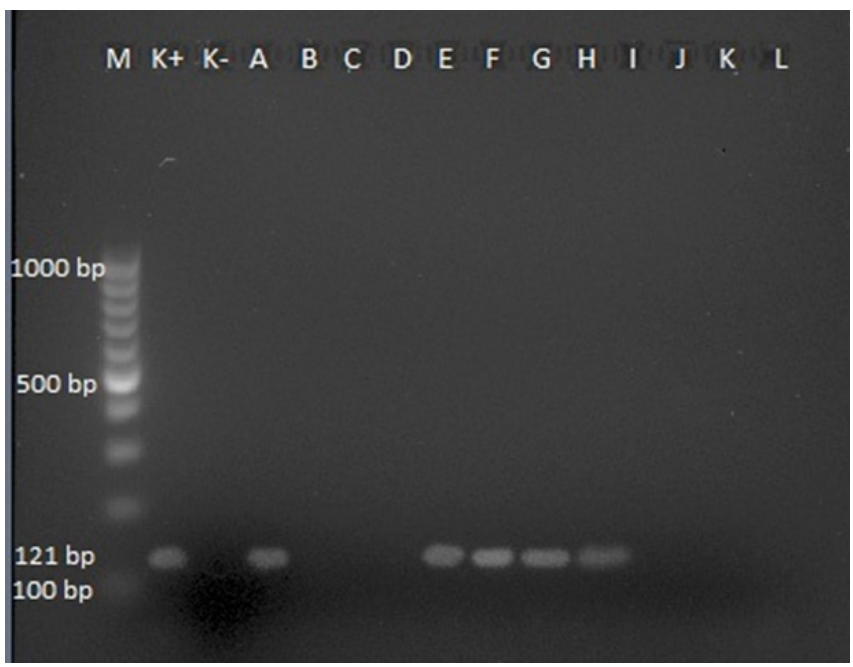

\begin{tabular}{|ll|}
\hline \multicolumn{2}{l|}{ Keterangan: } \\
$\mathrm{M}$ & : Marker \\
$\mathrm{K}+$ & : Kontrol positif \\
$\mathrm{K}-$ & : Kontrol negatif \\
$\mathrm{A}-\mathrm{L}$ & : Sampel susu bubuk kedelai
\end{tabular}

Gambar 6. Hasil amplifikasi DNA sampel susu bubuk kedelai dengan primer gen EPSPS-CP4

terdapat dalam sampel. Kegagalan amplifikasi dalam proses PCR dapat disebabkan pula karena adanya degradasi DNA sampel, jumlah DNA template yang tidak mencukupi serta adanya inhibitor yang menkontaminasi DNA (Nguyen dkk., 2009).

\section{Primer gen EPSPS-CP4}

Pasangan primer RRS0t-5 (forward) dan RRS0t-3 (reverse) memiliki area amplifikasi sebesar $121 \mathrm{bp}$ mengacu pada Tung dkk. (2008). Berdasarkan hasil visualiasi pada Gamber 6, primer gen EPSPS-CP4 dapat mengamplifikasi secara spesifik pada 5 sampel susu bubuk kedelai, yaitu sampel A, E, F, G, dan H dengan panjang pita 121 bp. Hal ini ditunjukkan dengan adanya pita DNA yang terlihat jelas, nyata meskipun samar. Sedangkan 7 sampel lainnya tidak terbentuk amplifikasi pita DNA.

Hasil sampel B, C, D, I, J, K, dan L tidak menunjukkan adanya gen EPSPS pada sampel. Hal ini diduga disebabkan oleh rusaknya DNA hasil ekstraksi dan purifikasi akibat proses pengolahan menggunakan pemanasan suhu tinggi. Proses pengolahan makanan yang kompleks memerlukan sejumlah langkah yang kasar dan bersifat negatif sehingga dapat mempengaruhi deteksi GMO (Bauer dkk., 2003). Proses pengolahan tersebut seperti memasak, pemanasan, tekanan tinggi, perlakuan $\mathrm{pH}$, gesekan fisik, dan pengaturan torsi tinggi. Dugaan lainnya adalah oleh penggunaan primer yang tidak spesifik, pada sampel mungkin menggunakan kedelai GMO, namun bukan kedelai Roundup Ready yang tahan 


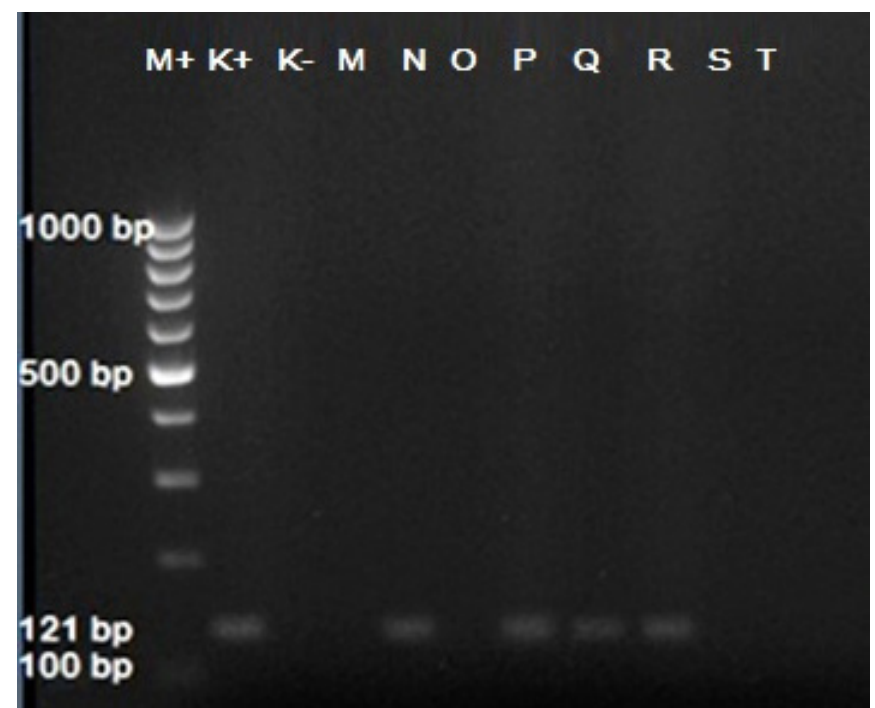

Keterangan:

$\mathrm{M}+$ : Marker

$\mathrm{K}+\quad$ : Kontrol positif

$\mathrm{K}-\quad$ : Kontrol negatif

M-T : Sampel susu bubuk

Gambar 7. Hasil amplifikasi DNA sampel formula soya dengan primer gen EPSPS-CP4

herbisida, sehingga primer EPSPS-CP4 tidak komplementer dengan DNA sampel.

Dapat dilihat pada Gambar 7, hasil amplifikasi sampel M, O, S, dan T tidak terbentuk pita DNA. Hal ini dapat disebabkan karena rusaknya DNA hasil ekstraksi dan purifikasi karena adanya proses pengolahan susu formula kedelai yang kompleks, seperti proses spray drying yang melibatkan panas. Proses pengolahan seperti memasak, pemanasan, pengeringan, tekanan tinggi, dan perlakuan $\mathrm{pH}$ dalam pengolahan makanan dapat mempengaruhi kondisi lingkungan yang dapat merusak atau mendenaturasi DNA dari protein. Sehingga hasil ekstraksi DNA sulit untuk ditemukan, karena DNA banyak yang terdegradasi sehingga sulit untuk dilakukan analisis lebih lanjut (Carson, 2006).

\section{Penggolongan GMO}

Penggolongan dalam GMO atau non-GMO dapat dilakukan dengan melihat ukuran pita yang teramplifikasi oleh primer. Jika sampel teramplifikasi pada ukuran pita yang sesuai dengan amplikon kontrol positif, diasumsikan sampel tersebut mengandung gen transgenik (positif GMO) (Rahmawati, 2011). Kesimpulan hasil elektroforesis terhadap sampel susu bubuk kedelai yang diamplifikasi oleh kedua primer dapat dilihat pada Tabel 5.
Tabel 5. Hasil amplifikasi DNA dengan primer CaMV 35S promotor dan gen EPSPS-CP4

\begin{tabular}{cccl}
\hline Kode sampel & $\begin{array}{c}\text { Primer CaMV } \\
\text { 35S promotor }\end{array}$ & $\begin{array}{c}\text { Primer gen } \\
\text { EPSPS-CP4 }\end{array}$ & + / - GMO \\
\hline K+ & + & + & GMO \\
K- & - & - & Non GMO \\
A & - & + & GMO \\
B & - & - & Non GMO \\
C & - & - & Non GMO \\
D & - & - & Non GMO \\
E & + & + & GMO \\
F & + & + & GMO \\
G & + & + & GMO \\
H & - & + & GMO \\
I & - & - & Non GMO \\
J & - & - & Non GMO \\
K & - & - & Non GMO \\
L & + & - & GMO \\
M & - & - & Non GMO \\
N & + & + & GMO \\
O & - & - & Non GMO \\
P & + & + & GMO \\
Q & - & + & GMO \\
R & + & GMO \\
S & - & Non GMO \\
T & + & - & GMO \\
\hline & & + &
\end{tabular}

Tidak teramplifikasinya gen EPSPS-CP4 atau gen CaMV 35S bukan berarti tanaman tersebut bebas dari rekayasa genetik. Kedelai GMO dapat menggunakan sisipan gen lain selain gen yang dideteksi pada penelitian ini, contohnya gen lectin (LEC) (Randhawa dkk., 2006), gen Cry1Ac (Sawazaki dkk., 2015) dan gen pinII (Hadiarto dkk., 2001). Suatu tanaman apabila tersisipi gen EPSPS-CP4 dan gen CaMV 35S dapat dipastikan bahwa tanaman tersebut merupakan GMO. Metode ini merupakan cara yang paling efisien untuk menentukan suatu tanaman tergolong GMO atau bukan, karena kedua gen tersebut paling umum digunakan pada kedelai transgenik komersial.

\section{KESIMPULAN}

Berdasarkan hasil optimasi, kondisi suhu annealing yang sesuai untuk proses PCR menggunakan Primer Promotor CaMV 35S yaitu pada suhu $60{ }^{\circ} \mathrm{C}$. Sedangkan untuk gen EPSPS-CP4, suhu annealing optimum yang diperoleh sebesar $59{ }^{\circ} \mathrm{C}$. Untuk primer NOS terminator tidak ditemukan suhu annealing yang optimum, hal ini dapat disebabkan karena kontrol positif yang digunakan tidak komplementer dengan 
primer. Dari amplifikasi DNA sampel, 6 sampel susu bubuk kedelai dan 5 sampel formula soya terdapat sisipan gen EPSPS-CP4 dan gen Promotor CaMV 35S. Dengan demikian 11 sampel tersebut dapat dikatakan sebagai PRG.

\section{DAFTAR PUSTAKA}

ACNFP. (2002). Monsanto Roundup Ready soybeans line 403-2. http://acnfp.food-.gov.uk. [15 Oktober 2015].

Bauer, T., Weller, P., Hammes, W.P. dan Hertel, C. (2003). The effect of processing on DNA degradation in food. Europan Food research and Technology 217: 338-343.

Carson, S. (2006). Manipulation and Expression of Recombinant DNA A Laboratory Manual Second Edition. Elsevier Academic Press, USA.

Chen, K., Han, H.dan Wang, X. (2012). A practicable detection system for genetically modified rice by SERS-barcoded nanosensors. Biosensors and Bioelectronics 34: 118124.

Grunewald, H. (2003). Optimization of Polymerase Chain Reaction. Dalam: Bartlett, J.M.S. dan Stirling, D. (ed.). Methods in Molecular Biology Vol 226: PCR Protocols Second Edition. Humana Press, New Jersey.

Hammond B.G. dan Jez, J.M. (2011). Impact of food processing on the safety assessment for proteins introduced into biotechnology-derived soybean and corn crops. Food and Chemical Toxicology 49(4): 711-721.

Handoyo, D. dan Ari, R. (2000). Prinsip umum dan pelaksanaan polymerase chain reaction (PCR). Jurnal Unesa 9(1): 17-29.

Hardi, Y. (2009). Reaksi PCR. http://sciencebiotech.net/ mengenal-pcr-polimerase-chain-reaction/. [16 Juni 2015].

Hadiarto, T., Utami, T.I.R., Pardal, S.J. dan Herman, M. (2001). Analisis molekuler gen pinii pada tanaman kedelai transgenik R2. Prosiding Seminar Hasil Penelitian Rintisan dan Bioteknologi Tanaman Bogor 133-140.

Ilhak, O.I. dan Arslan, A. (2007). Identification of meat species by polymerase chain reaction (PCR) technique. Turkish Journal Veterinary Animal 31(3): 159-163.

Folloni, S., Bellocchi, G., Kagkli, D.M., Benito, S.P., Aguilera, M., Mazzeo, A., Querci, M., Eede, G.V. dan Ermolli, M. (2011). Development of an ELISA reverse-based assay to assess the oresence of mycotoxin in cereal flour. Food Analytical Methods 4: 221-227.
Jankiewicz, A., Broll, H. dan Zagon, J. (1999). The official method for the detection of genetically modified soybeans: a semi-quantitative study of sensitivity limits with glyphosate-tolerant soybeans (Roundup Ready) and insect-resistant Bt maize (Mazimizer). European Food Research and Technology 209: 77-82.

Kilamanca, C.M. (2008). Sikap Konsumen Pasar Swalayan terhadap Produk Susu Kedelai di Kota Surakarta. Skripsi. Universitas Sebelas Maret, Surakarta.

Lipp, M., Bluth, A., Eyquem, F., Kruse, L., Schimmel, H., Eede, G.V. dan Anklam, E. (2001). Validation of a method based on polymerase chain reaction for the detection of genetically modified organisms in various processed foodstuffs. European Food Research and Technology 212(4): 497-504.

Meric, S. Cakir, O. Ari, S. dan Turqut, K.N. (2014). Detection of genetically modified maize and soybean in feed samples. Genetics and Molecular Research 13(1): 1160-1168.

Muladno (2010). Teknologi Rekayasa Genetika Edisi Kedua. Institut Pertanian Bogor Press, Bogor.

Nazir, M. (2005). Metode Penelitian. Ghalia Indonesia, Bogor.

Nguyen, T.C.T., Son, R., Raha, A.R., Lai, O.M. dan Michael C. (2009). Comparison of DNA extraction eficiencies using various methodes for the detection of genetically modified organisms (GMO). Journal International Food Research 16: 21-30.

Olson, P.S. (2015). Peran Tanaman Transgenik Semakin Nyata. http://tabloidsinartani.com/-content/read/perantanaman-transgenik-semakin-nyata/. [22 Agustus 2015].

Peccia, J. dan Hernadez, M. (2006). Incorporating polymerase chain reaction-based identification population characterization, and quantification of microorganisms into aerosol: A review. Atmospheric Environment 40(21): 3941-3961.

Pena, L. (2005). Trasngenic Plants: Methode and Protocol Methode in Molecular Biology Vol 286. Humana Press, New Jersey.

Putra, S.E.D., Tsuprykov, O., Websky, K.V., Ritter, T., Reichetzeder, C. dan Hocher, B. (2014). Dealing with large sample sizes: comparison of a new one spot dot blot method to Western blot. Clinical Laboratory 60: 1871-1877. 
Rahmawati (2011). Identifikasi Gen Transgenik pada Kedelai Impor dan Tempe di Kota Malang.Skripsi. Universitas Brawijaya, Malang.

Randhawa, G.J. dan Firke, P.K. (2006). Detection of transgenes in genetically modified soybean and maize using polymerase chain reaction. Indian Journal of Biotechnology 5: 510-513.

Sambrook, J.S. dan Russel, D.W. (2001). Molecular Cloning: A Laboratory Manual. Volume 1-3, Third Edition. Cold Spring arbour Laboratory Press, New York.

Sari, E.P.K. dan Wardani, A.K. (2015). Deteksi molekuler cemaran daging babi pada bakso sapi di pasar tradisional kota malang menggunakan PCR (polymerase chain reaction). Jurnal Pangan dan Agroindustri 3(4): 1294 1301.

Satria (2015). Produksi Kedelai Nasional Rendah. http://ugm. ac.id/. [15 Oktober 2015].

Sawazaki, H.E., Duarte, A.P., Fuzatto, M.G., Sawazaki, E., Grandi, S.H.R., Ponte, J.F. dan Noguire, L. (2015). Identification and quantification of corn, soybean and cotton genetically modified by real time PCR. American Journal of Molecular Biology 5: 84-93.
Sorina, M. Maria, B.O., Carasela, P. dan Elena, B. (2006). The GM (genetically modified) detection and quantification in different corn samples. Journal of Horticulture Forestry and Biotechnology: 398-401.

Termos Fisher Scientific (2008). Nanodrop 1000 Spectrophotometer V.3.7 User Manual. www.nanodrop. com/library/nd-1000-v3.7-users-manual-8.5x11.pdf. [23 Oktober 2015].

Tung, N.C.T., Son, R., Raha, A.R., Lai, O.M. dan Clemente M.W.V.L. (2008). Detection of genetically modified organisms (GMOs) using molecular techniques in food and feed samples from Malaysia and Vietnam. International Food Research Journal 15(2): 155-166.

Yusuf, Z.K. (2010). Polymerase chain reaction (PCR). Saintek 5(6): 1-6.

Yuwono, T. (2010). Teori dan Aplikasi Polymerase Chain Reaction. Andi, Yogyakarta. 